\title{
Artefacts Made from Siliceous Rocks of Polish Origin on Prehistoric Sites in the Czech Republic
}

\section{Antonín Přichystal ${ }^{a}$}

\begin{abstract}
Compared with Poland, the territory of Bohemia and Moravia is not so rich in natural occurrences of high-quality siliceous rocks (silicites, 'flints'). This contribution follows distribution of the four most attractive Polish chipped raw materials (silicite of the Cracow-Częstochowa Jurassic, 'chocolate' silicite, banded Krzemionki [striped] silicite and spotted Świeciechów [grey white-spotted] silicite) in the Czech Republic. Since the middle phase of Upper Palaeolithic (Gravettian) the Jurasssic-Cracow silicites had been transported to Moravia and since its late phase (Magdalenian) also to Bohemia. The first use of the 'chocolate' silicite has been ascertained at some Late Aurignacian (Epiaurignacian) sites of central Moravia similarly as an exceptional find attesting early use of Świeciechów spotted silicite (Late Szeletian?). No finds of the banded Krzemionki silicite have been registered in Pre-Neolithic flaked assemblages in the Czech Republic.

Evidence of systematic and mass transport of silicites from the Cracow-Częstochowa Jurassic to northern/central Moravia and to eastern/central Bohemia has been found in some periods of the Neolithic (especially connected with the Linear Pottery culture). For the period of the earlier Eneolithic (Funnel Beaker culture) we can identify a small but systematic presence of raw materials from the northern foreland of the Świętokrzyskie (Holy Cross) Mountains, this comprises objects of banded Krzemionki silicite and spotted Świeciechów silicite. About 24 Moravian non-stratified finds of axes made of the banded Krzemionki silicite and polished over the whole surface can be probably connected with the Globular Amphora culture. Silicites from the Cracow-Częstochowa Jurassic appeared again in the late Eneolithic, especially as arrowheads of the Bell Beaker culture in Moravia. Only two pieces made from the Jurassic Cracow-Częstochowa silicite appeared in a collection of I463 artefacts connected with the Early Bronze Age in Moravia.
\end{abstract}

KEY-WORDS: Polish silicites ('flints'), Czech Republic, Palaeolithic, Neolithic, Eneolithic, Early Bronze Age

\section{INTRODUCTION}

There are a number of characteristic siliceous rocks (silicites) that originated in the area that is now Poland. In the local archaeological literature, the ones that also played

a Institute of Geological Sciences, Masaryk University, Brno, Czech Republic; e-mail: prichy@sci.muni.cz; ORCID: 0000-000I-6653-04I6 
$36 \mid$ Prichystal

an important role also in the surrounding regions are usually termed Jurassic flint, banded (striped) flint, grey white-spotted (Świeciechów) flint and 'chocolate' flint. This contribution deals with the distribution of these flints in the Palaeolithic, Neolithic, Eneolithic and Early Bronze Age in the former lands of Czech Republic - Bohemia, Moravia and Czech Silesia. Until the First Petroarchaeological Seminar in Brno 1975, our older colleagues in former Czechoslovakia knew relatively little about Polish raw materials used for flaked tools and generally they considered almost all high quality siliceous raw materials at prehistoric sites in Czechoslovakia to be erratic flints from glacial deposits of Pleistocene continental ice sheets. On the other hand, already in 1937, Josef Skutil described six axes prepared from the banded Krzemionki flint and found in Moravia (Skutil 1937). Slavomil Vencl (1971: 74) drew our attention to occurrences of the Cracow flint in chipped collections connected with the Linear Pottery in eastern Bohemia and Moravia. Also flints of some Eneolithic axes or daggers were supposed to come from primary sources at the Baltic coast or in Scandinavia. Since 1975 the author has started cooperation with many archaeologists and geologists from Poland and in 1977 he sampled for the first time together with help of Krzysztof Sobczyk siliceous rocks from the Cracow-Częstochowa Jurassic. In recent time the Lithotheca of prehistoric raw materials at Masaryk University in Brno contains all common Polish flaked raw materials of Paleozoic, Mesozoic and Tertiary ages. In addition, the author published their basic characterisation in water immersion under the stereomicroscope and in petrographic thin sections using the polarising microscope (Přichystal 2009, 20I3).

\section{WHY THE AUTHOR PREFERS THE TERM SILICITE INSTEAD OF FLINT}

The term flint and its local equivalents (in Polish it is 'krzemien', in Czech 'pazourek') originated very early and without clear definition. It appears in Polish written communications for the first time in Cracow in 1568 (Król and Migaszewski 2009), in the Czech language substantially later, in the first half of the inth century in connection with the first German - Czech dictionary. Before this, in both countries they used only the word for 'stone making fire', i.e., Feuersteine (in Polish 'skałka' or 'krzesak', in Czech 'křesací kámen') and this term covered various rocks and minerals including flint. It is evident that both words 'krzemien' and 'pazourek' were originally also used in the same wide sense, i.e., stone for making fire.

The recent Polish petrographic definition of flint and chert ('krzemien' and 'rogowiec') is based on the siliceous rock shape: nodular siliceous rock is termed flint and the term used for layered varieties is chert (for example Żaba 2006: 231, 373). Since the end of the I9th century (Dana 1895: 28I), the English and American geological dictionaries usually define flint as a variety of chert that occurs commonly as nodules 
and bands in (Cretaceous) chalk (e.g., Bates and Jackson eds 1987; Allaby and Allaby eds 2003) whereas chert (older synonym hornstone, now not recommended) forms 'nodules sometimes becoming continuous layers in other limestones'. Czech and Slovak petrologists have used similar definitions based on the age and origin of the siliceous rock. Michael Brandl (20IO) published the same opinion as the Austrian view on the classification of these raw materials. A typical entry in a recent sedimentological dictionary might be: 'Chert occurs in nodules and in strata (bedded or ribbon cherts). Common synonyms for cherts include flint' or 'Flint is the other common name for chert. It occurs in both nodular and bedded forms' (e.g., Garrison 20I0: 175). It is evident the classification of flint and chert cannot be based on the shape of siliceous rocks.

As a consequence of different opinions current in various countries, the author prefers to use the comprehensive and geologically well-defined term silicite with more detailed specification using the name of source locality, i.e., banded Krzemionki silicite (because there is also the banded Stránská skála chert in Brno, banded Pęgów flint in Poland, banded flint from glacial deposits from various places in central Europe) or the spotted Świeciechów silicite (because we know of various spotted Jurassic cherts also in Moravia or in Bavaria). As a matter of fact, in the Polish archaeological literature the term 'krzemien' (or its English equivalent flint) is used in a very broad sense corresponding to the geological chert or silicite.

The term silicite started to be used by Russian specialists in sedimentary petrography in the first half of the 2oth century. It was introduced to English speaking scientists by Sergei Ivanovich Tomkeieff (1983) in his Dictionary of Petrology. The term covers all varieties of chert, including flint. The term chert is recommended only for marine silicite (Príchystal 20IO). Because of the long tradition of differentiation between northern flint and local cherts in Central Europe, the author has proposed defining flint as a variety of chert (silicite) originating in the Upper Cretaceous (Maastrichtian) chalk or Lowermost Tertiary (Danian) Bryozoan limestone (we are not able very often to differ between Maastrichtian and Danian flints in Pleistocene deposits of extensive glaciated areas of Poland, Germany and the Czech Republic). Besides marine cherts, it is necessary to distinguish limnosilicites of freshwater origin. In cases of different terminology or if we are not sure of siliceous rock determination, the best resolution seems to be the use of the neutral term silicite.

\section{SILICITES OF THE CRACOW-CZĘSTOCHOWA JURASSIC (SKCJ), ESPECIALLY VARIETY A ('KRZEMIEŃ JURAJSKI PODKRAKOWSKI') AND VARIETY G}

There is no reliable evidence for the occurrence of this material on Middle Palaeolithic and early Upper Palaeolithic (Bohunician) sites in the Czech Republic. A Middle Pal- 
$38 \mid$ Prichystal

aeolithic side scraper made of the SKCJ (Fig. I) was found, it is true, at an Eneolithic hillfort Starý Zámek near Jevišovice (western Moravia) but is believed to have been brought there and reutilised a community of the Funnel Beaker culture (Šebela et al., 2017). Two tools (an end scraper and a side scraper) come from the Szeletian locality Drysice I - Kluče and four cores made of the SKCJ have been described from a Late Szeletian(?) site Rozdrojovice near Brno (Oliva 200I: 84), the cultural classification of the last locality is a matter of question because Zdeňka Nerudová (20I6) considers it to be an Epigravettian site. As far as Aurignacian and Epiaurignacian sites in central Moravia are concerned, because of the strong patina it is very difficult to distinguish possible occasional occurrences of the SKCJ among the erratic flints that dominate these assemblages. Martin Oliva (200I: 85) mentioned rare flaked tools made of the SKCJ: one combined tool from Bělov I (Kroměříz district), one borer from Míškovice (Kroměríz district) and one end scraper found at Dubicko (Šumperk district).

Without doubt, items of SKCJ are regularly present on some south- and eastMoravian Gravettian localities as has already been mentioned by Janusz K. Kozłowski (1958). Their presence has been described from Pavlov II, Dolní Věstonice I, Jarošov II, Spytihněv I with the estimated quantity for example at Pavlov II of up to $27 \%$, possibly $38 \%$ when the collection is evaluated without waste (Oliva 2007: 49). Surprisingly, there is almost no occurrence of SKCJ (only two pieces) at the famous Gravettian

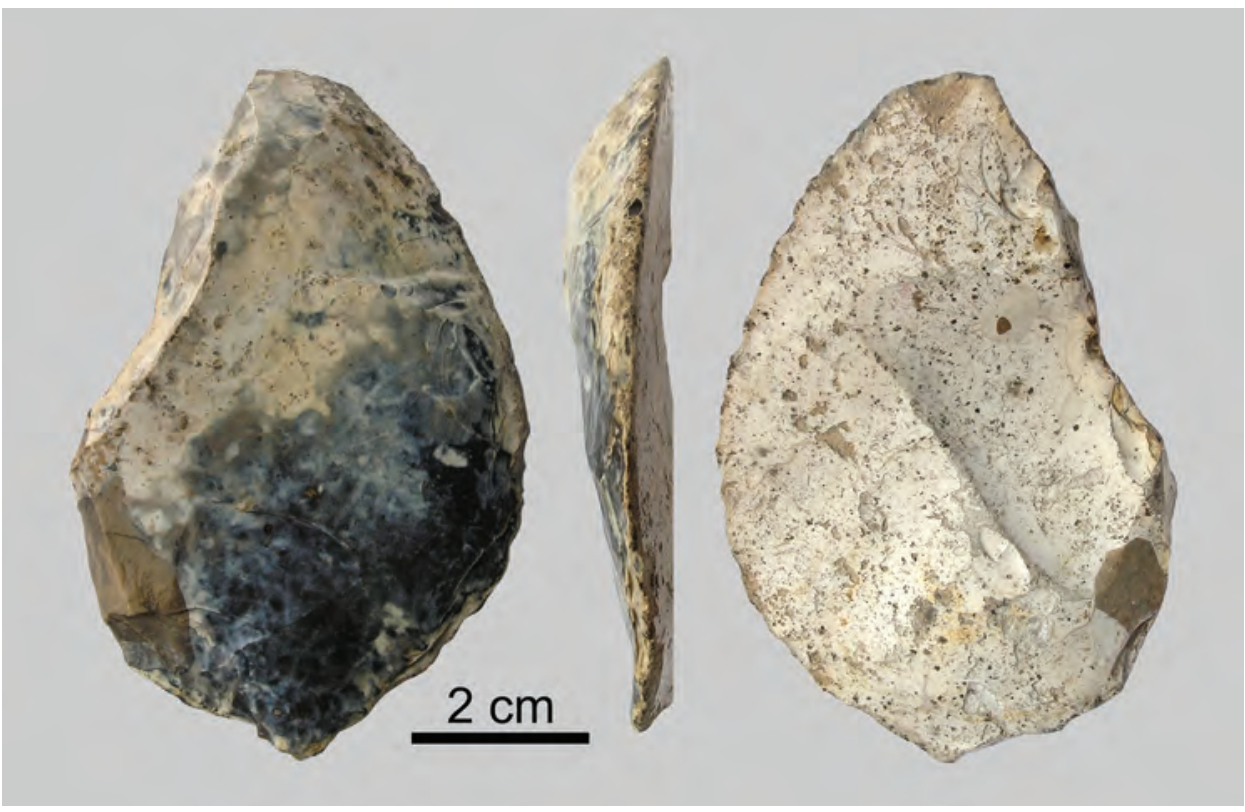

Fig. 1. Middle Palaeolithic side scraper, silicite of the Cracow-Częstochowa Jurassic. Jevišovice-Starý Zámek, Znojmo distr., south-western Moravia. Photo: L. Plchová. 
site of Přerov-Předmostí. There were no occurrences at the three localities in Brno, generally accepted as the Epigravettian, i.e., Brno-Stránská skála IV, Brno-Jundrov and Brno-Štýrice. The SKCJ appeared occasionally among the raw materials used by the Magdalenian hunters in caves of the Moravian Karst: Pekárna cave - 2\% from studied 592 cores (Voláková 200I: I09); Ochozská cave - under 0.5\%. A very small amount of the SKCJ has been found at some Late Palaeolithic and Mesolithic sites (Smolín, Přibice, Dolní Věstonice) in Moravia.

In Bohemia, there is no evidence of the presence of Polish siliceous raw materials in the Early Upper Palaeolithic (Bohunician?, Leaf Point complexes, Aurignacian) and in the middle phase of the Upper Palaeolithic (Gravettian). The first small occurrence of the silicites of Polish origin has been noted only in the Magdalenian collections from Tmaň - Děravá jeskyně and Putim (Vencl and Fridrich eds 2007: IOI).

A real mass transport of Jurassic silicites from south Poland to Moravia, Silesia and Bohemia started at the beginning of the Neolithic when in some phases of the Linear Pottery culture (LBK) they even represented the prevalent raw material: Bylany in central Bohemia (LBK II-III, 46\% of SKCJ; Ivan Pavlů and Antonín Přichystal in Přichystal 1985), Bravantice near Studénka (LBK IIb); Žopy I, Kladníky, Šišma, Mohelnice (LBK I; Mateiciucová 2000: 232, 2008: I26). In spite of its position within a glaciated area with natural occurrences of erratic flints, the Linear Pottery culture micro-region around Studénka very probably played an important mediation role in the distribution of the SKCJ further to the south (Janák et al., 2016), where around Přerov, i.e., in the southern part of the Bečva Gateway, we know again of settlements with flaked industries rich in SKCJ silicite (Mateiciucová 2000, 2008; Schenk 2007): Kladníky I, LBK Ia, 65\% of SKCJ; Přerov-Dluhonice II, LBK IIb, 95\% of SKCJ or Šišma. LBK settlements with prevalent SKCJ raw material occur around the southern entrance of the Moravian Gateway through the Carpathian mountains: at Práslavice (Olomouc district) $73 \%$ of SKCJ; Žopy (Kroměříz district) 63\% of SKCJ (Mateiciucová 2008) and probably other sites (Fig. 2).

This distribution on a mass scale is connected with extensive raw material mining in the source area (Dzieduszycka-Machnikowa and Lech 1976; Lech 1980). After the period of Linear Pottery culture, the raw material occurred in substantially smaller quantities on several sites of the succeeding Stroked Pottery and Lengyel cultures. Janák and Přichystal (2007) published a detailed analysis of the distribution of SKCJ in Moravia during the Neolithic and the beginning of the Eneolithic. In central Moravia, the distribution of this raw material culminated probably already in the LBK Ia phase, in surrounding areas mostly from phase Ib or II. At the end of the Stroked Pottery culture (SBK IV) and the beginning of Lengyel culture (Lg I) and especially in the transitional period $\mathrm{LgI} / \mathrm{LgII}$ it is possible to note again a rather higher supply of the SKCJ to Moravia. Małgorzata Kaczanowska and Janusz K. Kozłowski (1976: 213) found the Jurassic Cracow silicite at a Lengyel settlement near Těšetice-Kyjovice, Znojmo 


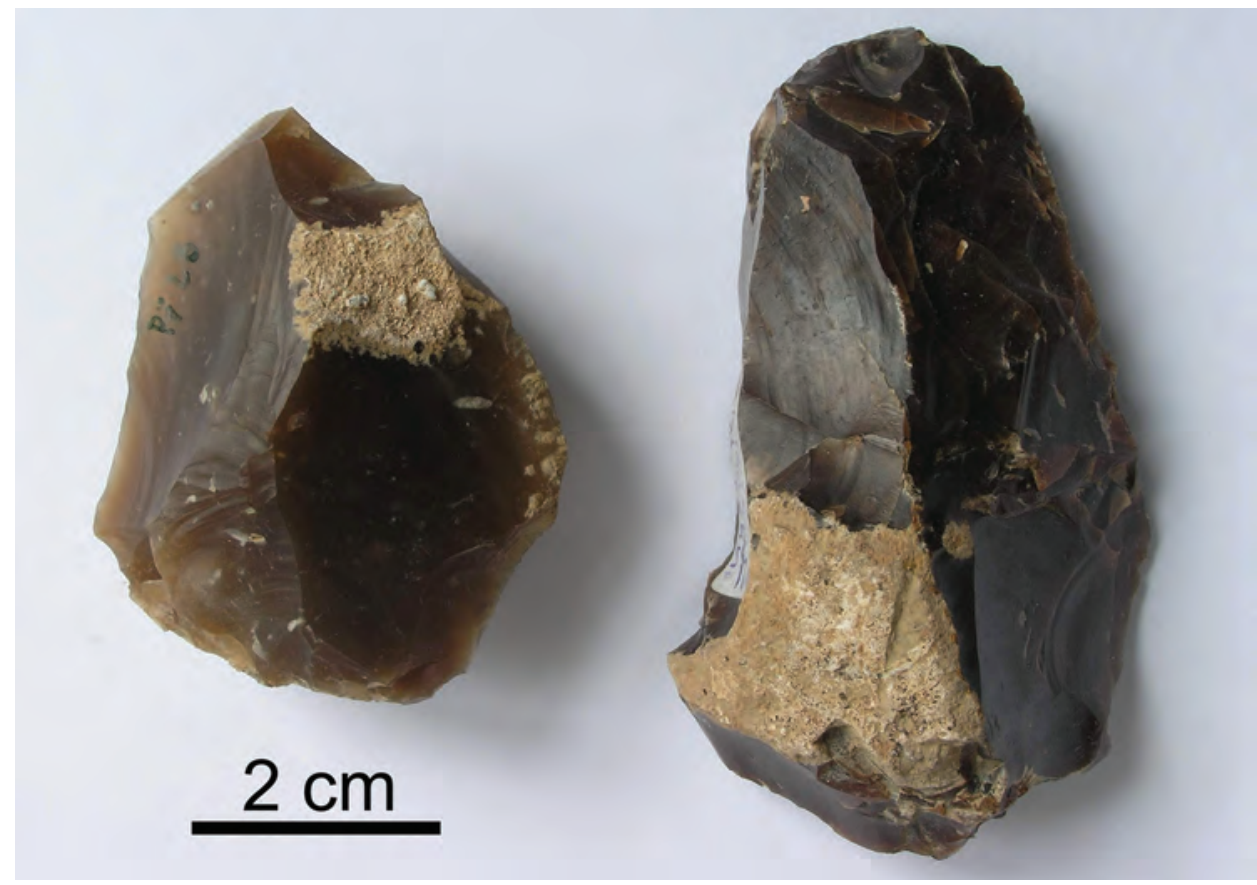

Fig. 2. Neolithic (probably Linear Pottery culture) chips, silicite of the Cracow-Częstochowa Jurassic. Slatinice, Olomouc distr., central Moravia. Photo: A. Přichystal.

district, but according to our recent knowledge, its presence is not so high (only about I\%). Going to the west in Bohemia, the occurrence of SKCJ material declines considerably, for example in a small collection of 45 pieces from the LBK settlement at Kosor (Praha-west district) it was used for only 2 artefacts (Nerudová and Přichystal 20II: 83).

In eastern/central Bohemia, SKCJ are also present in flaked assemblages of the Stroked Pottery culture but substantially less in comparision with older LBK assemblages, for example at Bylany, about I2\% (Pavlů and Přichystal in Přichystal 1985), at Mšeno, district Mělník (a collection of 3128 artefacts, excavations of M. Lička) there were found only 4 pieces, i.e., under 0.1\%, because of the near total dominance of silicites from glacial sediments (Prichystal 1987). On the other hand, SKCJ have been described more far to the west from Chráštany near Rakovník (Lech 1993).

Raw materials of the SKCJ group occurred in the early Eneolithic is concerned, for example at the famous hillfort Hlinsko (Funnel Beaker culture) near the Moravian Gateway (only 7 pieces, i.e., around $0.2 \%$ ), and also at other hillforts of the same period lying more to the south (the Prostějov area). So far, not a single piece of SKCJ material has been noted at the hillfort of Staré Zámky in Brno-Líšeň, where we know one piece of spotted Świeciechów silicite and two axes made of the banded Krzemionki silicite. In deposits of the young Eneolithic cultures in Moravia (the Jevišovice, Bošáca 
Artefacts Made from Siliceous Rocks of Polish Origin on Prehistoric Sites in the Czech Republic

and Globular Amphorae cultures; the Eneolithic in Moravia has been subdivided into several stages, usually five or six, including young, late and final; e.g., Kopacz et al., 2OI4: 4), the presence of SKCJ among flaked artefacts seems to be very rare and accidental. Occurrences of siliceous axes made of the SKCJ, variety G, are connected with the late Eneolithic Corded Ware culture in central Moravia. Surprisingly, the SKCJ, variety A, was used as an important raw material especially for arrowheads in the period of the Moravian Bell Beaker culture: 75 pieces altogether, it is II\% of the whole Moravian collection (Kopacz et al., 2009). Probably from the Eneolithic period comes also a small deposit of three long blades ( $\mathrm{I} 2-\mathrm{I} 4 \mathrm{~cm}, \mathrm{SKCJ}$, variety G) from Bernartice nad Odrou, northern Moravia (Janák et al., 2004).

The utilisation of SKCJ during the Early Bronze Age in Moravia (the Únětice culture and the Věteřov group) was very low. The material (I463 artefacts) from 86 Moravian localities was studied (for more details see Kopacz and Šebela 2006) and among them, only two items were of this raw material (Přichystal 2006).

\section{'CHOCOLATE’ SILICITE (CHoS, 'KRZEMIEŃ CZEKOLADOWY’)}

The 'chocolate' silicite appeared for the first time at Late Aurignacian (Epiaurignacian) sites Slatinice near Olomouc and Lhotka near Kroměríž. Oliva (200I: 85) has discussed one piece from the Aurignacian site of Bělov I. The raw material is present ( $0,3 \%$ from 592 cores; Voláková 200I) in the Magdalenian settlement in the Pekárna Cave (Moravian Karst). In Bohemia, the 'chocolate' silicite was ascertained very rarely at Late Palaeolithic sites Voletiny near Trutnov or Světlá nad Sázavou (eastern Bohemia). It was found at more Mesolithic sites in southern Moravia (Smolín, Přibice, Dolní Věstonice). The Mesolithic collection from Hořín near Mělník (central Bohemia) contains probably I piece.

At the Neolithic localities with Linear Pottery the 'chocolate' silicite occurs only as individual pieces - at Bylany, Kolín (central Bohemia), Mohelnice (?) in northern Moravia. Pavel Burgert in this volume has evaluated the role of 'chocolate' silicite in the Neolithic of Bohemia (Burgert 20I8). He mentions its occurrences on settlements of the Stroked Pottery culture especially during the later phase IV. The find spots are spread in eastern Bohemia, prevalently in the area of the Elbe right bank between Jaromer and Hradec Králové (ChoS up to $2 \%$ of the assemblage) where he has described even a workshop at Plotiště nad Labem (almost 9\% of the ChoS in the assemblage).

This raw material occurs in small quantities in Moravian Painted Ware assemblages in southern Moravia. Two pieces were ascertained at the Funnel Beaker hillfort at Čechovsko near Prostějov. Only three Eneolithic axes made of 'chocolate' silicite have been found in Moravia, but none in Bohemia or in Czech Silesia (Šebela et al., in preparation). One Late Eneolithic dagger made of 'chocolate' silicite (Fig. 3) was found 
$42 \mid$ Prichystal

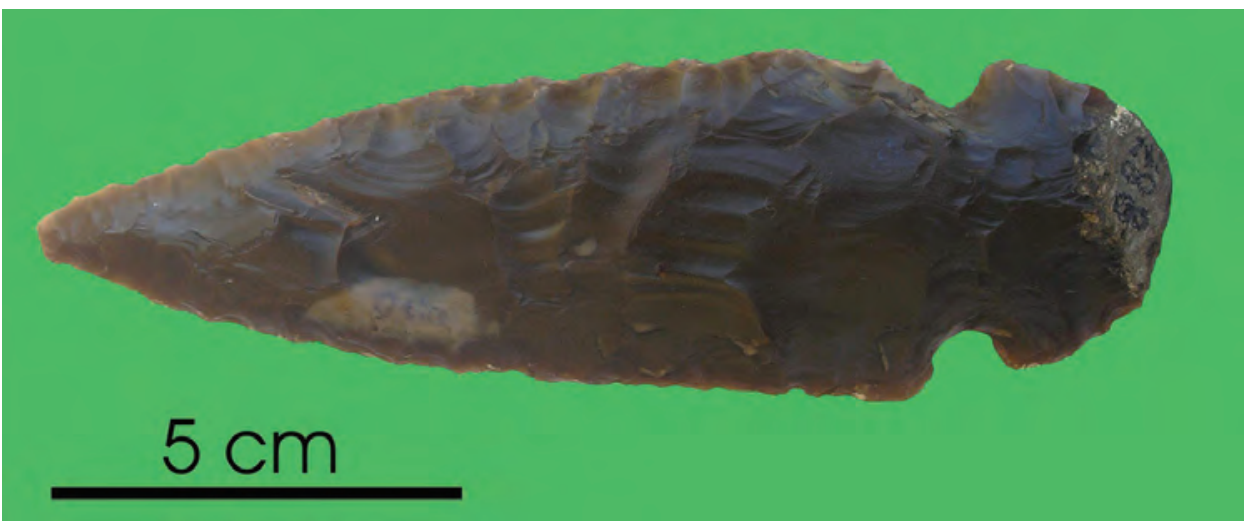

Fig. 3. Late Eneolithic dagger, 'chocolate’ silicite. Osice, Hradec Králové distr., eastern Bohemia. Photo: L. Plchová.

at Osice, eastern Bohemia (Přichystal and Šebela 2015), probably of the Early Bronze Age. Three flaked artefacts including two arrowheads made of the $\mathrm{ChoS}$ have been described from a grave of the Bell Beaker culture in Praha - Velká Chuchle (Přichystal and Šebela 2009).

\section{SPOTTED ŚWIECIECHÓW SILICITE (SwS, 'KRZEMIEŃ NAKRAPIANY ŚWIECIECHOWSKI’ OR 'GREY WHITE-SPOTTED’)}

The raw material was used for a leaf-shaped point found at an Upper Palaeolithic site Míškovice-Křemenná near Holešov (Kozłowski 1972-73: 13), in recent time classified as the Aurignacian influenced by the Szeletian (Svoboda et al., 2009: 163). One artefact was probably also found at the Szeletian site of Drysice I, central Moravia (Přichystal 200I). Only individual pieces were found in the Magdalenian collections from the Kůlna and Pekárna caves in the Moravian Karst (Valoch 1987). No finds have been described from the Moravian or Bohemian Mesolithic. In the Neolithic period, four pieces have been found connected with the Linear Pottery settlement at Bylany (Bohemia) and Mohelnice (Moravia). One piece was also announced from the Stroked Pottery culture site at Lobeč, NE of Mělník in Bohemia, (Spurný 1951: 134).

Perfectly flaked tools (scrapers, retouched blades) occur almost always as a few pieces at hillforts of the Funnel Beaker culture in central Moravia: Hlinsko near Lipník (32 pieces, i.e., about I\%), Čechovsko (7 pieces, i.e., I\%) and Ohrozim (I piece) near Prostějov (Šmíd and Přichystal 20I5: 93, I48). The southernmost find (I piece) was ascertained at Staré Zámky near Brno-Líšeň (Fig. 4). Six axes made of the spotted 


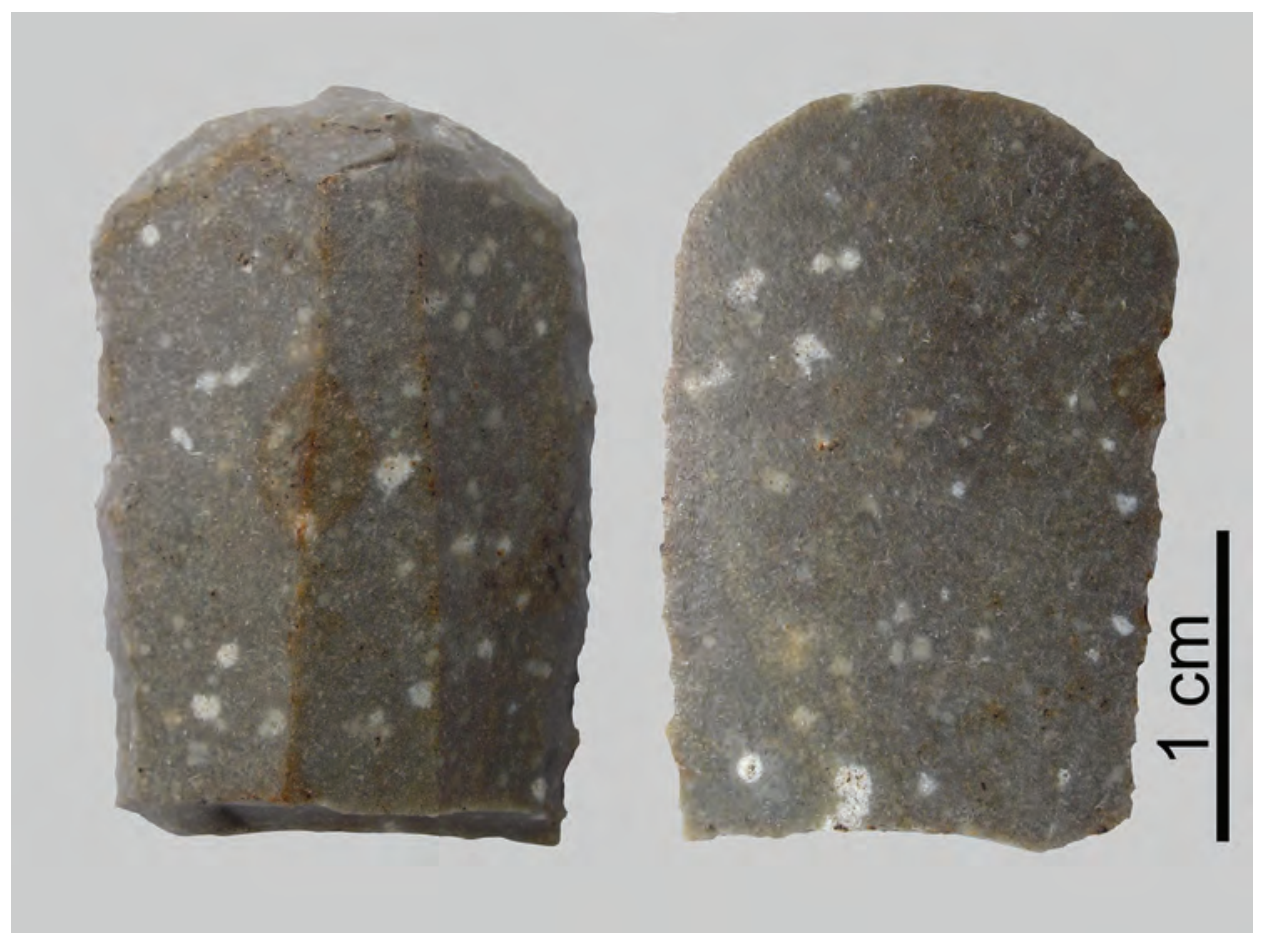

Fig. 4. Eneolithic (Funnel Beaker culture) end scraper, spotted Świeciechów silicite. Brno-Líšeň, Staré Zámky, Brno-město distr., southern Moravia. Photo: L. Plchová.

Świeciechów silicite (Lhotka, Nezamyslice, Velehrad, Veselíčko, Bezměrov, Želešice) are connected with the Corded Ware culture in Moravia (Šebela et al., in preparation).

In Bohemia, finds of the spotted Świeciechów silicite connected with the Funnel Beaker culture are absolutely exceptional - a blade from Mradice (Neustupný et al., 2008). No Late Eneolithic axes manufactured from the spotted Świeciechów silicite have been described from Bohemia (Šebela et al., in preparation).

\section{BANDED KRZEMIONKI SILICITE ( KrS, 'KRZEMIEŃ PASIASTY’)}

There are no reliable data about the presence of this material on Palaeolithic or Mesolithic sites in the Czech Republic. Žebera (1958: 143) mentioned the presence of Krzemionki banded flint at a Mesolitic (in his text Tardenosian) locality Liblín (correctly Libín) near Hořice, district Jičín, NE Bohemia, but this seems to be very unlikely and, according to personal communication from Slavomil Vencl, the raw material is probably a variety of erratic flint. 
$44 \mid$ Prichystal

Does this characteristic Polish silicite appear for the first time as occasional individual chips at some Neolithic sites around the Moravian Gateway? Inna Mateiciucová (2008) has not mentioned it at all among Neolithic raw materials in Moravia. Petr Gadas found a chip of the Krzemionki banded silicite at Šišma III Amerika, district Přerov (Fig. 5), the locality is usually classified to the Linear Pottery culture but according to polished tools made of Culmian siltstone at the same place, the Funnel Beaker culture occurrence is also almost sure and the chip should be more probably connected with this culture.

Archaeological excavations at a hillfort of the Funnel Beaker culture at Hlinsko near Lipník nad Bečvou revealed 5 flaked artefacts and one polished axe. Other reliably documented occurrences of the Krzemionki silicite in Moravia are represented by 24 silicite axes of the Eneolithic age, according to their shape connected with the Globular Amphorae culture (Šebela et al., in preparation). Two axes from the Eneolithic hillfort Staré Zámky in Brno-Lišseň represent the southernmost finds on the Bohemian Massif in Moravia (Fig. 6).

Three axes made of the banded Krzemionki silicite have been found also in eastern/central Bohemia: Denemark near Kutná Hora - Ǩivnáč culture (Zápotocký 20I2: 132); Slatiny, south of Jičín - of the Bell Beaker culture and Mladotice (Chrudim district) - probably Krzemionki banded silicite, an accidental find (Šebela et al., in preparation).

\section{CONCLUSION}

Without doubt, the four most spectacular Polish silicites ('flints') were also used as raw materials in prehistoric times in Moravia, Czech Silesia and eastern/central Bohemia. Regular occurrences of silicites from the Cracow-Częstochowa Jurassic (evidently from its southern part around Cracow) appeared besides the prevalent erratic flints from northern Moravia or Silesia at some south and east Moravian Gravettian sites. The author believes the most probable explanation of their substantial presence at these localities can be connected with seasonal migrations of the Gravettian hunters through depressions between the Bohemian Massif and the West Carpathians and subsequently along the Carpathian bend up to the Cracow area. In Bohemia, SKCJ have been found in only two Magdalenian collections. Their utilisation during the Moravian Epigravettian, Late Palaeolithic and Mesolithic seems to be only accidental, probably with the exception in the Magdalenian with small but systematic occurrence in caves of the Moravian Karst. Transport of SKCJ to northern /central Moravia and eastern/ central Bohemia on a really mass scale started with the Linear Pottery culture. The material is present in smaller quantities in lithic collections of succeeding Neolithic and Eneolithic cultures. Surprisingly, SKCJ is present in substantial quantities in the 


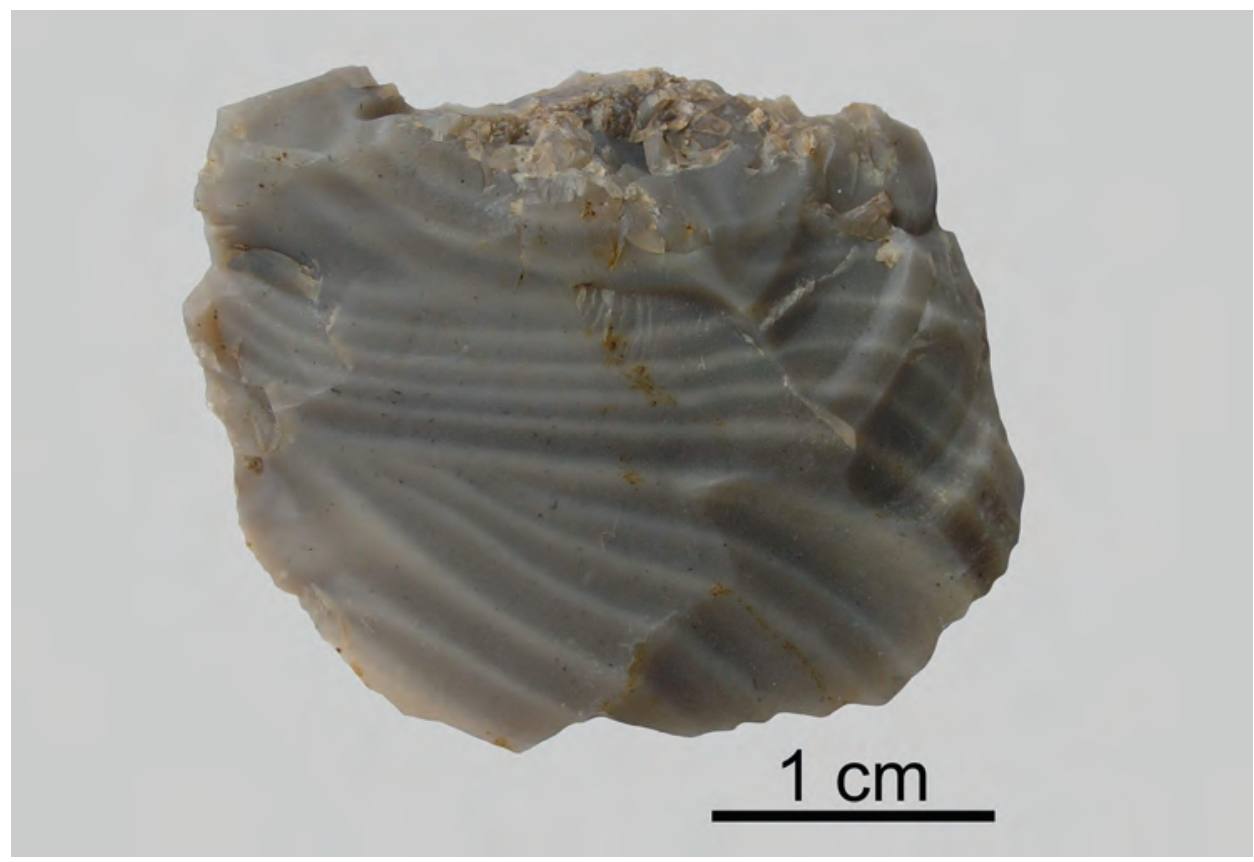

Fig. 5. Eneolithic (probably Funnel Beaker culture) chip, banded Krzemionki silicite. Šišma, Přerov distr., central Moravia. Photo: L. Plchová.

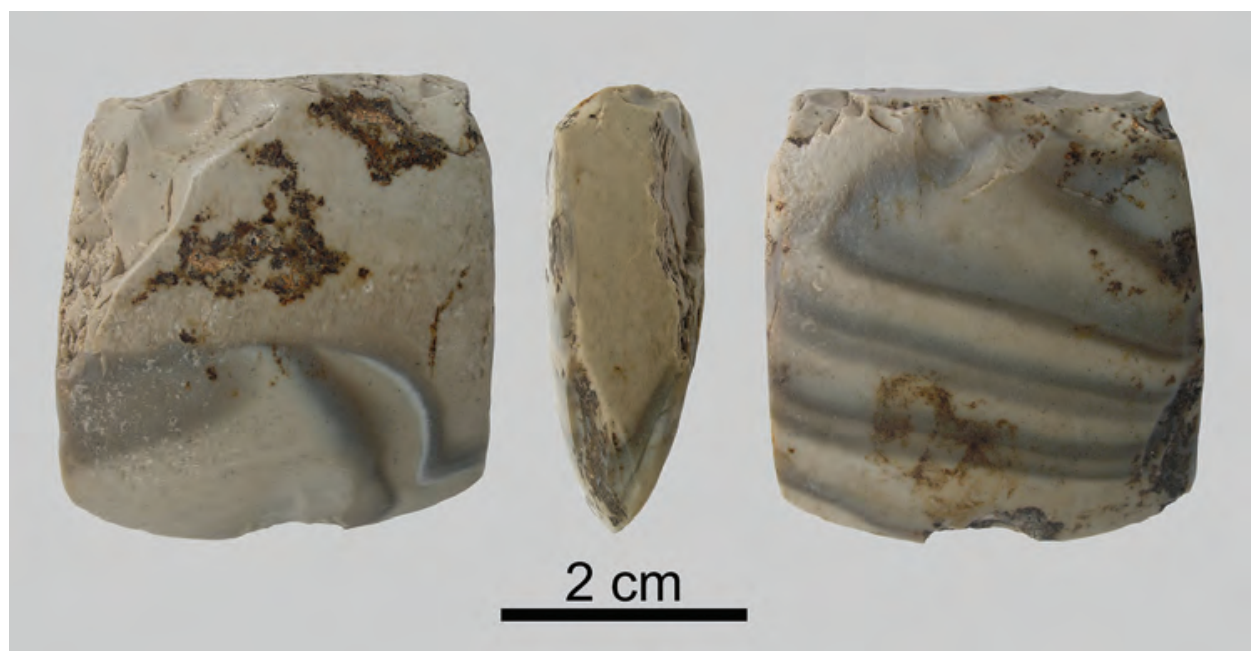

Fig. 6. Eneolithic silicite axe, banded Krzemionki silicite. Brno-Líšeň, Staré Zámky, Brno-město distr., southern Moravia. Photo: L. Plchová. 
$46 \mid$ Prichystal

arrowheads of the Bell Beaker culture in Moravia. Their occurrence in Early Bronze Age findspots in Moravia is very rare (only 2 pieces in the collection of I463 artefacts).

Only small amounts of 'chocolate' silicite appeared in central Moravia maybe even earlier that the SKCJ at some south-and east-Moravian Gravettian sites, but it is connected with the Late Szeletian or Epiaurignacian cultures. It is undoubtedly present among the raw materials of the Magdalenian settlement in the Moravian Karst (about I\% at Pekárna Cave) and as accidental finds at Late Palaeolithic and Mesolithic localities in Moravia and Bohemia. Only sometimes do the Neolithic and Eneolithic flaked collections in both regions have a few pieces of the 'chocolate' silicite. According to our current knowledge, an exception is represented by the settlements of the Stroked Pottery culture in eastern Bohemia, especially along the Elbe between Jaromer and Hradec Králové, these are relatively rich in the ChoS. Individual pieces were found rarely in collections connected with the Funnel Beaker culture (Prostějov-Čechovsko, central Moravia).

Spotted Świeciechów silicite appeared for first time at two Upper Palaeolithic sites in central Moravia, classified as the Szeletian or the Aurignacian influenced by the Szeletian. Only individual pieces were found in the Magdalenian assemblage from the Kůlna and Pekárna caves in the Moravian Karst. No finds have been ascertained in the Moravian and Bohemian Mesolithic. SwS occurs in small quantities at some important Neolithic sites in Bohemia and Moravia as accidental pieces. A regular presence in small quantities is typical for the Funnel Beaker culture in Moravia. Four silicite axes in Moravia (none in Bohemia) are considered likely to be from the Corded Ware culture period.

There are no reliable records of the occurrence of the banded Krzemionki silicite in the Palaeolithic and Mesolithic of Moravia, Bohemia and Czech Silesia. Very scarce chips of the Krzemionki silicite are related to the Early-Middle Eneolithic (prevalently Funnel Beaker culture), and found in the southern part of the Moravian Gateway. But Moravia is relatively rich in surface finds of silicite axes made of the banded Krzemionki silicite (about 24 pieces). In northern and central Moravia they are linked with the Globular Amphora culture, in southern Moravia they are classified as imports into the milieu of the Jevišovice culture.

\section{REFERENCES}

Allaby, A. and Allaby, M. (eds) 2003. A Dictionary of Earth Sciences (2nd edition). Oxford.

Bates, R. L. and Jackson, J. A. (eds) 1987. Glossary of Geology (3rd edition). Alexandria.

Brandl, M. 20Io. Classification of rocks within the chert group: Austrian practice. Archeometriai Mühely 2010 (3): 183-190.

Burgert, P. 2018. The Status and the Role of 'Chocolate' Silicite in Bohemian Neolithic. Archeologia Polona 56: 49-64. 
Dana, E. S. 1895. Minerals and how to study them. A book for beginners in mineralogy. New Haven.

Dzieduszycka-Machnikowa, A. and Lech, J. 1976. Neolityczne zespoty pracowniane z kopalni krzemienia w Sąpowie. Wrocław-Warszawa-Kraków-Gdańsk, Ossolineum.

Garrison, E. G. 20I0. Techniques in Archaeological Geology. Berlin, Springer. Natural Science in Archaeology.

Janák, V., Oliva, M., Přichystal, A., and Grepl, E. 2004. Hromadný nález silicitových čepelí z Bernartic nad Odrou, okr. Nový Jičín. In E. Kazdová, Z. Měrínský and K. Šabatová (eds), Kpoctě Vladimíru Podborskému, I67-175. Brno.

Janák, V., Papáková, K., Přichystal, A., Kováčik, P., Rataj, P. and Hořínková, A. 20I6. Neolitické osídlení v okolí Studénky a úloha zdejš́ho mikroregionu kultury s lineární keramikou v distribuci silicitů krakovsko-čenstochovské jury. Slovenská archeológia 64 (I): I-63.

Janák, V. and Přichystal, A. 2007. Distribuce silicitů krakovsko-čenstochovské jury na Moravě a v Horním Slezsku v neolitu a na počátku eneolitu. Památky archeologické 98: 5-30.

Kaczanowska, M. and Kozłowski, J. K. 1976. Studia nad surowcami krzemiennymi południowej części Wyżyny Krakowsko-Częstochowskiej. Acta Archaeologica Carpathica I6: 20I-20I6.

Kopacz, J. and Šebela, L. 2006. Kultura unietycka i grupa wieterzowska na Morawach na podstawie materiatów krzemieniarskich. Kraków.

Kopacz, J., Přichystal, A. and Šebela, L. 2009. Lithic chipped industry of the Bell Beaker culture in Moravia and its East-Central European context. Kraków-Brno.

Kopacz, J., Přichystal, A. and Šebela, L. 20I4. Lithic Chipped Industry of the young Eneolithic in Moravia and Czech Silesia. Brno. Spisy Archeologického ústavu AV ČR 46.

Kozłowski, J. K. 1958. Przyczynek do znajomości surowców krzemiennych występujących w paleolicie i neolicie ČSR. Wiadomości Archeologiczne 25: 355-360.

Kozłowski, J. K. 1972-73. The origin of lithic raw materials used in the Palaeolithic of the Carpathian countries. Acta Archaeologica Carpathica I3: 5-19.

Król, P. and Migaszewski, Z. M. 2009. Rodzaje, występowanie i geneza krzemieni. Zarys problematyki. In P. Król (ed.), Historia krzemienia, I2-45. Kielce.

Lech, J. 1980. Flint Mining among the Early Farming Communities of Central Europe. Przeglad Archeologiczny 28: 5-55.

Lech, J. 1993. Analyse der Spaltindustrie aus der Grube 2. In M. Zápotocká, Chráštany, Bez. Rakovník. Ein Beitrag zum chronologischen Verhältnis der Stichtbandkeramik zur Grossgartacher und Oberlauterbacher Keramik. Archeologické rozhledy 45/3: 436-459.

Mateiciucová, I. 2000. Časně neolitická štípaná industrie z osady Kladníky a Ivanovice na Moravě. In Památky archeologické - supplementum I3: 218-237.

Mateiciucová, I. 2008. Talking Stones: The chipped Industry in Lower Austria and Moravia and the Beginnings of the Neolithic in Central Europe (LBK), 5700-4900 BC. Brno - Praha, Dissertationes archaeologicae Brunenses/Pragensesque 4 .

Nerudová, Z. 2016. Lovci posledních mamutů na Moravě. Brno, Moravské zemské muzeum, Studie Centra kulturní antropologie 2.

Nerudová, Z. and Přichystal, A. 20Ir. Kamenná štípaná industrie. In M. Lička, Osidlení kultury slineární keramikou v Kosoři, okr. Praha-západ. Praha, Fontes Archaeologici Pragenses 37: 78-86.

Neustupný, E., Dobeš, M., Turek, J. and Zápotocký, M. 2008. Archeologie pravěkých Čech / 4. Eneolit. Praha.

Oliva, M. 200I. Gravettienská sídliště u Pavlova. K otázce využívání silicitů krakovské jury. Acta Musei Moraviae, Scientiae sociales 86: 45-99.

Oliva, M. 2007. Gravettien na Moravě. Brno - Praha, Dissertationes archaeologicae Brunenses / Pragensesque I. 
$48 \quad$ Prichystal

Přichystal, A. 1985. Štípaná industrie z neolitického sídliště v Bylanech (okr. Kutná Hora) z hlediska použitých surovin a jejich provenience. Archeologické rozhledy 37: 48I-488.

Přichystal, A. 1987. Petrografický výzkum štípané industrie ze Mšena (okr. Mělník). Praha, Manuscript of report. Národní muzeum v Praze.

Přichystal, A. 200I. Zastoupení kamenných surovin na szeletských stanicích Drysice I a Ondratice IV (okres Prostějov, Vyškov). Pravěk NŘ 2000 (Io): 35-39.

Přichystal, A. 2006. Surowce kamienne morawskich inwentarzy krzemieniarskich z wczesnego okresu epoki brązu. In Kopacz, J. and Šebela, L., Kultura unietycka i grupa wieterzowska na Morawach na podstawie materiatów krzemieniarskich, 37-45. Kraków.

Přichystal, A. 2009. Kamenné suroviny v pravěku východni části středni Evropy. Brno.

Přichystal, A. 20Io. Classification of lithic raw materials used for prehistoric chipped artefacts in general and siliceous sediments (silicites) in particular: the Czech proposal. Archeometriai Mühely (3): I77-I82.

Přichystal, A. 2013. Lithic raw materials in prehistoric times of eastern Central Europe. Brno.

Přichystal, A. and Šebela, L. 2009. Př́spěvek k poznání kamenné štípané industrie z pohřebiště kultury zvoncovitých pohárů v Praze-Velké Chuchli. Archeologie ve středních Čechách I3: 683-686.

Prichystal, A. and Šebela, L. 20I5. Silicite daggers from the territories of the Czech Republic and Slovakia (a preliminary study). In C. J. Frieman and B. V. Eriksen (eds), Flint daggers in prehistoric Europe, I33-I48. Oxford-Philadelphia.

Schenk, Z. 2007. Jihozápadní část Moravské brány v době kultury s lineární keramikou. Archeologické studie Univerzity Hradec Králové I: 2II-244.

Skutil, J. 1937. O znaleziskach siekierek z tzw. pasiastego krzemienia na Morawach. Przeglad Archeologiczny 6: 105-106.

Spurný, V. 195I. Neolitické sídliště v Lobči. Archeologické rozhledy 3: 130-I35.

Svoboda, J., Havlíček, P., Ložek, V., Macoun, J., Musil, R., Přichystal, A., Svobodová, H. and Vlček, E. 2009. Paleolit Moravy a Slezska (3. aktualizované vydání). Brno, Dolnověstonické studie I6.

Šebela, L., Přichystal, A., Král, L. and Král, P., in preparation. Silicite axes from the lands Moravia, Bohemia and Czech Silesia. Brno, Spisy AÚ AV ČR v Brně.

Šebela, L., Přichystal, A., Škrdla, P. and Humpolová, A. 20I7. Unusual Middle Paleolithic Stone Tool from Southern Moravia with Possible Relations to Southern Poland. Acta Archaeologica Carpathica 52: 3-IO.

Šmíd, M. and Přichystal, A. 20I5. Eneolitická hradiska na Prostějovsku. Ohrozim - Čubernice a Prostějov - Čechovice-Čechovsko. Brno, Pravěk - Supplementum 29. ÚAPP Brno.

Tomkeieff, S. I. 1983. Dictionary of Petrology. Chichester.

Valoch, K. 1987. Raw materials used in the Moravian Middle and Upper Palaeolithic. In K. T. Biró (ed.), International conference on prehistoric flint mining and lithic raw material identification in the Carpathian Basin, 263-268. Budapest-Sümeg.

Vencl, S. I97I. Současný stav poznání postmesolitických štípaných industrií v Československu. In $Z$ badań nad krzemieniarstwem neolitycznym i eneolitycznym, 74-99. Kraków-Nowa Huta.

Vencl, S. and Fridrich, J. (eds) 2007. Archeologie pravěkých Čech / 2. Paleolit a mezolit. Praha.

Voláková, S. 200I. K technologii štípané industrie magdaléninu: analýza jader z jeskyně Pekárny. Acta Musei Moraviae 86: IOI-II6.

Zápotocký, M. 20I2. Silicitové sekery v eneolitu a starší době bronzové Čech. Archeologie západních Čech 4: I26-159.

Żaba, J. 2006. Ilustrowana encyklopedia skat i mineratów. Katowice.

Žebera, K. 1958. Československo ve starši době kamenné. Praha. 